UDC 005:004

DOI: https://doi.org/10.30839/2072-7941.2018.149651

\title{
INFORMATION MANAGEMENT AS A FACTOR OF INNOVATIVE SOCIETY DEVELOPMENT
}

\author{
(C) MELNYK, V.V. \\ National Pedagogical Dragomanov University (Kyiv, Ukraine) \\ E-mail: doc.v.melnik@mail.ru, ORCID: 0000-0001-5976-5823
}

\begin{abstract}
The relevance of the topic of research of information management as a modern direction of the development of society is that in the 21 st century the development of modern civilization has accelerated in the direction of globalization - economic, political, and cultural. The central problem for the development of informational civilization is information as one of the most important attributes and resources of human activity, which grows into knowledge.

The problem of research is information management as a science that is not yet sufficiently developed in modern scientific literature; therefore, it is very important to study all new approaches to its development. The purpose of the research is the conceptualization of information management as a science, based on information and communication technologies and informatization mechanisms that help to identify the information and innovation potential of our country, develop information standards and implement intellectual human capital based on information. The article substantiates the essence, tasks and main directions of the development of the concept of information management, determined by informationalism. The transition to a new information civilization has the character of a "technocratic project", based on the innovative development of society, which is based on the information infrastructure. The development of information management is promoted by the "knowledge society", which cultivates a creative person, the formation of which is based on information and knowledge. The research tasks are the conceptualization of information management, its essence, content and main directions of development, which are introduced into the practice of the educational process of high school. The methodological basis for the formation and development of the concept of the information society is informationalism, studied by M. Castells (2000), as well as Autopoese methodology of Maturana and Varela. The results of the research are the formation of the concept of information management as one of the most modern trends in the development of the 21 st century society, which is quite innovative, requiring the development of an informative and innovative society and an informative and innovative personality. Conclusions - the concept of information management should be introduced in all areas of the development of society, including high school, which requires the formation of a creative personality as a subject of an informative and innovative society.
\end{abstract}

Key words: information management, information, information civilization, information society, informatisation

The problem is presented in general terms and its connection with important scientific or practical tasks

The essence of the concept of information management as a science is determined by the development of information and communication technologies that determine the rating of a country and its promotion to the level of competitive one.

The main directions of development are based on the foundations - economic, educational, 
cultural, which contribute to the improvement of the information foundations of society and the formation of a creative and innovative personality.

Information management as a science is intended to deepen the value of the scientific and categorical forms of information discourse, which contributes to the formation of innovative information personality as the main intellectual resource of the society [1, p.189-193].

Analysis of recent research and publications

We rely on the works of V.Voronkova, O.Kivlyuk, A.Lazarevich, M.Maksimenyuk, V.Nikitenko, O.Punchenko, which present the main conceptual aspects of information and communication management, its essence, characteristics and main features.

The purpose of the research is the conceptualization of information and communication management as a factor in the development of an innovative society and finding ways to optimize it.

\section{Methodology of the research}

The concept of information management as a new direction in the development of society includes methods and approaches that allow one to penetrate into its essence:

1. An economic approach that considers the issues of attracting new information based on usefulness, efficiency, innovation.

2. Analytical approach, which is based on an analysis of the needs of users of information and communication.

3. An organizational approach that considers information technologies in the context of their influence on organizational processes and considering information and communication management as a multicomponent structure.

4. A systematic approach that considers the processing of information on the basis of a holistic, system-oriented, comprehensive process of information processing.

5 . The hermeneutic method is used to analyze information and communication links within a certain cultural environment.

Selection of unexplored parts of the general problem. Unsolved earlier part of the general problem.

The problem of research is information management as a science that is not yet sufficiently developed in modern scientific literature; therefore, it is very important to study all new approaches to its development.

The purpose of the research is the conceptualization of information management as a science, which is based on information and communication technologies and informatization mechanisms that help identify the information and innovation potential of our country, the development of information standards and the implementation of intellectual human capital, which is based on information.

Therefore, the transition to an information civilization is in the context of globalization - economic, political, cultural, educational - the nature of "technocratic projects", based on the information development of society [2, p.128-133].

This goal is realized in a number of tasks: 
- to justify information management as a science and practical activity;

- to characterize information management;

- to form the concept of information management.

\section{Presenting main material.}

Information management as a science and practice

Information management as a science must comply with the technological structure of production and the management system, which is based on information and communication technologies and contributes to the strengthening of its organizational culture.

The intellectual potential of society is designed to resist the destructive tendencies of society, which necessarily necessitates the formation of a creative and creative personality, which turns information into creative processes. Information and communication management has the character of "technocratic projects":

1) communication management;

2) information resource management;

3) management of information processing. Information management is a set of rules, technical methods and systems that define the information and communication structure of an organization, determining the purposeful use of information as the main resource.

The concept of "integrated information management" includes the creation of such an information structure, where all the "pieces" of information provide the necessary level of coincidence of all information components. Information management is considered as an additional function in the business, focused on resources; its content includes the tasks of information retrieval and the development of information systems [3].

\section{Characteristics of information management}

Information is one of the most important economic resources, a factor of production and a decisive factor of competitiveness, which requires purposeful coordination. Information management is becoming the most important task of the development of modern society and is an essential factor in the success of entrepreneurial activity.

The essence of information management is that an entrepreneurial information infrastructure should be coordinated using three tasks:

1) formations (building information systems - people, information resources, information and communication technologies);

2) management (information process management);

3) development (permanent ability of information systems to adapt to a rapidly changing environment).

The goal of information management is to optimally support the business processes of an entrepreneurial strategy and thereby ensure its competitiveness.

The sphere of information management includes several components of information:

1) information;

2) information and communication technologies;

3) individual consumers of information. Information management 
as a concept and a new methodology is fundamental to organizations and has significant integrated potential for sustainable development.

\section{Research results}

As a result of the study of empirical material collected on information management, we came to the conclusion that information management provides a systematic presentation of knowledge in the amount necessary for the information and communication development of the organization as a systemic whole and a single social organism.

The results of the research indicate that there are many definitions of information management in the scientific world:

1) it is sometimes considered as synonymous with organizational management of data processing;

2) in other cases, it is identified with the communication and information processes of the organization, which is associated with a broader interpretation of information as a resource representing an independent production factor that underlies decision making.

From the standpoint of a systematic approach, information management covers the planning, organization, coordination and control of information activities and processes, as well as to improve its work [4, p. 222-226].

The concept of information management is reduced to:

1) high-quality information support of the organization's management processes;

2) ensuring management of information processing at all levels;
3) ensuring communication management. The content of information management is determined by the concept of the development of a new independent sphere of knowledge - communication and information sciences, which correspond to the development paradigm of society and have their own specifics along with other sciences (social, humanitarian, technical, natural science).

Information management is closely related to the theory of information and communication, the history of mass communications, the information infrastructure of the society, the theory of the information society and the knowledge society, information and communication policies, information law.

Information management as a science covers information resources, information systems, telecommunications, information and communication technology and technologies, methods for researching information systems.

Information management should be analyzed in the context of such approaches as organizational communication, information services and marketing, methods of organizing public relations, financing information activities, commercial law, advertising semiotics. Informationalism is a new way of development, created by the restructuring of the mode of production at the end of the twentieth century. Insofar as informationalism is based on knowledge and information technologies, the information mode of development foresees a close relationship between culture and productive forces. 
One of the methods of information quality in information management is its characteristic in terms of temporal, semantic and formal measurements, which include time, content and form, which in their triune whole characterize high-quality information (table 1).

Characteristics of high quality information

Table 1

Time measurements

\begin{tabular}{|l|l|}
\hline Receipt of information as necessary & Timeliness \\
\hline Rapid reproduction of information & Relevance \\
\hline Availability of information about the past, present and future & Periodicity \\
\hline Semantic measurement & \multicolumn{2}{|l|}{} \\
\hline Reliability of information & Accuracy \\
\hline Compliance with the requirements of a particular user & Feasibility \\
\hline Providing all necessary information & Completeness \\
\hline Providing only the necessary information & Concision \\
\hline Formal measurements & \\
\hline Information is provided in a simple and understandable form & Clarity \\
\hline Providing more accurate information & Detail \\
\hline Providing information in a detailed, digital or spatial-visual & Visuality \\
form & \\
\hline
\end{tabular}

Information management concerns all management functions of modern organizations, as well as communication and decision-making processes. Information management includes a general methodology for working with information in management structures.

The general goal of information management is the production of operational information for the organization and ensuring effective management of all resources, for which it is necessary to create an innovative program and technical environment for managing the organization.

Among the strategic objectives of the organization of the information society is the creation of an information infrastructure of the organization and the management of information and communication technologies.

The main task of information management is information support for the organization's activities [5, p. 46-50].

The task is to: work with large amounts of information and use it wisely; master modern information and communication technologies and determine the priority and directions of modernizing society using the technologies of the fifth or sixth technological order, ensure the development of the society "advanced ahead" and efficiently use the technologies of the sixth technological order

(nanotechnology, biotechnology, robotics); to form the most effective organization management system for a network society. 
The concepts of information management vary across a wide spectrum: from the traditional understanding of information services to the general theory of management.

The following generalizations of the object and subject of information management research should be singled out:

1) information support (in the broadest sense of the word);

2) information resources and their management;

3) information services and entrepreneurship;

4) information systems and their management;

5) processing and analysis of information;

6) office management;

7) the organization of communication;

8) management of information and communication technologies $[6, \mathrm{p}$. 266-278].

Information management is the result of the information technology revolution, which is the modern stage in the development of scientific and technological progress, in which information is the most important strategic resource and tool for managing social and natural processes, and new technologies are the determining factor in social development.

\section{Conclusions:}

1. Ukraine has used a lot of funds for the development of the information society at the state level, many state programs have been adopted for the further technologization of society.

2. The strategy for solving informatization problems in Ukraine is outlined in the National Informatization Program, the general bases for the formation, execution and use of which are defined by the Law of Ukraine "On the National Informatization Program" (1998), which consists of the Concept of the National Informatization Program, strategic goals and based principles of state policy in the information sphere.

3 . Today there are many different types and types of information knowledge - the economy of information and communication technologies, network economics, economics of global processes, economics of intellectual property, innovative economics, investment economics, information economics, social economics, knowledge economics, which are based on information management [7].

4. Information management contributes to the development of the state information policy, improving the management of the country's economy, the development of knowledge-intensive industries and high technologies, and the improvement of social and economic relations. Information management is the management of an organization's activities in order to use information in the interests of the organization itself and to ensure its effective development.

5. The concept of information management should be introduced in all areas of social development, including higher education, which requires the formation of a creative personality as a subject of the information-innovative society.

\section{Recommendations}


1. To develop informatization, as a result of which the mass of new directions in science, culture, economics, management, business, which gradually changes the area of social reality and human spiritual life, has been developed.

2. High school must form a global (informational) manager, ready to work in the conditions of the information revolution and possess information management competencies.

3. To develop informational and informational and communicative management as new directions in the science of the 21 st century, which will contribute to the informational and communicative progress of society and civilization.

\section{References}

1. Voronkova, V. G. (2017). The formation of the smart community as a factor of sustainable development and its influence on the formation of a new educational paradigm. Gìleâ, 117 (2), 189-193.

2. Voronkova, V. G., Romanenko, T. P., Andrûkajtene, R. (2017). Genesis from the information society to the "smart-society" in the context of the historical evolution of the modern world: theoretical-conceptual context. Gìleâ, 116 (1), 128-133.

3. Castells, M. (1996-1998). The Information Age: Economy, Society and Culture. Vol. III. Oxford: Blackwell Publishers, 625.

4. Kyvliuk, O. P. (2014). Modelling of information processes in the context of the information society. Gileâ, 80, 222-226.

5. Kyrychenko, M. O. (2017). Informatization as the factor of optimization of the ideology of the information society in terms of network-communicative space. ScienceRise: Pedagogical Education, 1 (9), 46-50. doi: https://doi.org/10.15587/2519-4984.2017.91627

6. Maksimenûk, M. Yu., Nikitenko, V. O. (2016). Informational and communicative society as a kind of complex social systems and interaction. Humanitarian Bulletin of Zaporizhzhya State Engineering Academy, 66, 266-278.

7. Melnik, V. V. (2014). Formation of the concept of information management: essence, objectives, main directions of development. Humanitarian Bulletin of Zaporizhzhya State Engineering Academy, 56, 208-217.

МЕЛЬНИК, В. В. - кандидат філософських наук, доцент кафедри управління, інформаційно-аналітичної діяльності та євроінтеграції,

Національний педагогічний університет імені М. П. Драгоманова (Київ,Україна)

E-mail:doc.v.melnik@mail.ru, ORCID:0000-0001-5976-5823

\section{ІНФОРМАЦІЙНИЙ МЕНЕДЖМЕНТ ЯК ФАКТОР РОЗВИТКУ ІННОВАЦІЙНОГО СУСПІЛЬСТВА}

\section{Анотація}

Актуальність теми дослідження інформаційного менеджменту як сучасного напрямку розвитку суспільства в тому, що в умовах XXI століття укорінився розвиток сучасної цивілізації у напрямі глобалізації - економічної, політичної, культурної. Центральною темою для розвитку інформаційної цивілізації є інформація як один 3 самих важливих атрибутів і ресурсів людської діяльності, що переростає у знання. Проблема дослідження - інформаційний менеджмент як наука, що недостатньо ще розроблений у сучасній науковій літературі, тому надзвичайно важливо вивчити всі 
нові підходи до його розвитку. Мета дослідження - концептуалізація інформаційного менеджменту як науки, в основі якого виступають інформаційно-комунікативні технології та механізми інформатизації, що впливають виявленню інформаційноінноваційного потенціалу нашої країни, розвитку інформаційних стандартів та реалізації інтелектуального людського капіталу, в основі якого інформація. В статті обгрунтовується сутність, завдання та основні напрямки розвитку концепції інформаційного менеджменту, детерміновані інформаціоналізмом. Перехід до нової інформаційної цивілізації носить характер «технократичного проекту», в основі якого інноваційний розвиток суспільства, що базується на інформаційній інфраструктурі. Розвитку інформаційного менеджменту сприяє «суспільство знань», яке культивує креативну особистість, формування якої базується на інформації та знаннях. Завдання дослідження - концептуалізація інформаційного менеджменту, його сутності, змісту та основних напрямків розвитку, які упроваджуються у практику освітянського процесу вищої школи. Методологічною основою становлення i розвитку концепції інформаційного менеджменту є інформарціоналізм, що досліджується М.Кастельсом (2000), а також аутопоезисна методологія Матурани і Варели. Результати дослідження - упровадження концепції інформаційного менеджменту як одного з самих сучасних напрямків розвитку суспільства XXI століття, достатньо інноваційного, що й вимагає розвитку інформаційно-інноваційного суспільства та інформаційно-інноваційної особистості. Висновки - концепцію інформаційного менеджменту слід упроваджувати на всіх напрямках розвитку суспільства, включаючи і вищу щколу, яка вимагає формування креативної особистості як суб'єкта інформаційно-інноваційного суспільства.

Ключові слова: інформаційний менеджмент, інформація, інформаційна цивілізація, інноваційне суспільство.

МЕЛЬНИК В. В. - кандидат философских наук, доцент кафедры управления, информационно-аналитической деятельности и евроинтеграции, Национальный педагогический университет имени М. П. Драгоманова (Киев,Украина)

E-mail: doc.v.melnik@mail.ru, ORCID: 0000-0001-5976-5823

\section{ИНФОРМАЦИОННЫЙ МЕНЕДЖМЕНТ КАК ФАКТОР РАЗВИТИЯ ИННОВАЦИОННОГО ОБЩЕСТВА}

\section{Аннотация}

Актуальность темы исследования информационного менеджмента как современного направления развития общества в том, что в условиях XXI века ускорилось развитие современной цивилизации в направлении глобализации экономической, политической, культурной. Центральной проблемой для развития информационной цивилизации является информация как один самых важных атрибутов и ресурсов человеческой деятельности, которая перерастает в знание.

Проблема исследования - информационный менеджмент как наука, который недостаточно еще разработан в современной научной литературе, поэтому очень важно изучить все новые подходы к ее развитию. Цель исследования - концептуализация информационного менеджмента как науки, в основе которой выступают информационно-коммуникативные технологии и механизмы информатизации, способствующие выявлению информационно-инновационного потенциала нашей страны, развитию информационных стандартов и реализации интеллектуального человеческого капитала, в основе которого информация. В статье обосновывается сущность, задачи и основные направления развития концепции информационного менеджмента, детерминируемые информационализмом. Переход к новой информационной цивилизации носит характер «технократического проекта», в основе 
которого инновационное развитие общества, которое базируется на информационной инфраструктуре. Развитию информационного менеджмента способствует «общество знаний», которое культивирует креативную личность, формирование которой базируется на информации и знаниях. Задачи исследования - концептуализация информационного менеджмента, его сущности, содержания и основных направлений развития, которые внедряются в практику образовательного процесса высшей школы. Методологической основой становления и развития концепции информационного общества есть информационализм, исследуемый М. Кастельсом (2000), а также аутопоезисная методология Матураны и Варелы. Результаты исследования формирование концепции информационного менеджмента как одного из самых современных направлений развития общества XXI века, достаточно инновационной, требующей развития информационно-инновационного общества и информационноинновационной личности. Выводы - концепцию информационного менеджмента следует внедрить на всех направлениях развития общества, включая и высшую школу, которая требует формирования креативной личности как субъекта информационноинновационного общества.

Ключевые слова: информационный менеджмент, информация, информационная цивилизация, инновационное общество.

Стаття рекомендована до публікації д.філософ.н., проф. В.Г.Воронковою (Запоріжжя, Україна)

Надійшла до редколегіï: 10.10.2018 Прийнята до друку: 15.10.2018 